anisms can go a long way toward placing the current Senate in perspective. To this end Hibbing and Alford examine the two chambers' patterns of switches in partisan control, levels of turnover, swing ratios (seat change over vote change), and tipping points (vote change required to reverse partisan control). In each case the evidence points to electoral convergence between the two chambers, and there is even some suggestion of a reversal of their constitutionally intended roles. They close with a consideration of the causes of these historic shifts, and an assessment of the operational and policy consequences that flow from them.

The CQ Press Award is given by the Legislative Studies Section each year to honor outstanding scholarship as reflected in the papers presented at each year's national meeting. Consideration for this prize is not limited to papers presented at panels organized by the Legislative Studies Section or at APSA Legislative Politics panels, but honors the best papers on legislative politics presented at any panel at the APSA meeting.

The 1989 CQ Press Award Committee is chaired by Melissa P. Collie of the University of Texas. Other members are Alan Abramovitz of Emory University and Wayne L. Francis of the University of Florida. The 1989 prize will be announced and conferred at the 1989 Awards Ceremony of the Legislative Studies Section held during and in conjunction with the Annual Meeting of the American Political Science Association in Atlanta. It will honor the best paper in legislative politics delivered at the 1988 APSA Annual Meeting.

\section{Richard F. Fenno, Jr. Prize for 1988 Announced; Award Committee for 1989 Set}

The Legislative Studies Section of the American Political Science Association an-

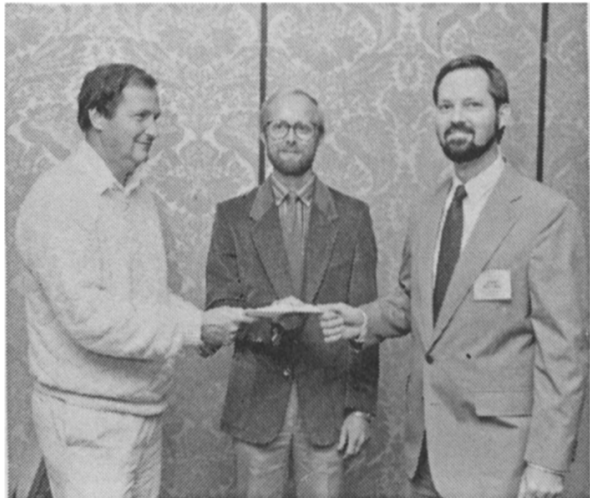

David Brady presents Legislative Studies Section's CQ Press Award to John R. Hibbing and John Alford.

nounced the 1988 winner of the Richard $F$. Fenno, Jr. Prize at the LSS Awards Ceremony held in Washington at the APSA Annual Meeting. The Fenno Prize honors the outstanding book published during the preceding year in legislative studies, including American, non-American, crossnational, and sub-national works.

The 1988 Fenno Prize was conferred jointly upon Bruce Cain, John Ferejohn, and Morris Fiorina for their book The Personal Vote: Constituency Service and Electoral Independence, published in 1987 by Harvard University Press. Other members of the Fenno Committee were Diana Evans, Trinity College, and Stephen Frantzich, the U.S. Naval Academy.

Speaking on behalf of the Fenno Prize Committee, Diana Evans reported:

The Personal Vote: Constituency Service and Electoral independence by Bruce Cain, John Ferejohn, and Morris Fiorina, is a carefully crafted study of the role played by constituency service in the electoral fortunes of members of the United States House of Representatives and the British House of Commons. It resolved a major paradox in the literature: that district service has increased in volume and perceived importance to members over the years, but seems not to have had large effects on their electoral fates. The authors convincingly demonstrate that we have been looking in the wrong place: the effects are substantial, but indirect. Politicians do indeed know what they are doing. Cain, Ferejohn and 


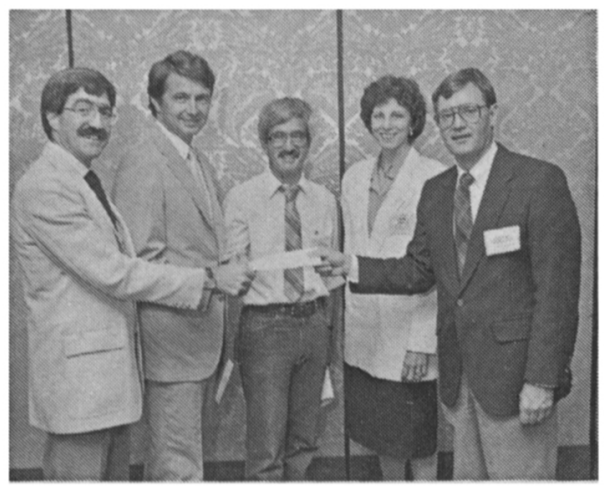

Stephen Frantzich (r. to 1.) and Diana Evans present 1988 Fenno Award to John Ferejohn, Bruce Cain and Morris Fiorina.

Fiorina showed us how to study constituency service, and how to understand its effects.

They argue further that the electoral connection is critical to legislative policy-making. As a result of the substantial personal vote in these two, single member district systems, the legislatures are more fragmented and decentralized than they would be if voters were motivated solely by partisan considerations. Public policy in the two systems is therefore more particularistic.

The Fenno competition for 1989 will include books published at any point during the 1988 calendar year, and will be judged by a Fenno Prize Committee made up of Morris Fiorina of Harvard University, Chairman, and Gerhard Loewenberg of the University of lowa and Professor Suzanne Parker of Florida State University. Authors and others interested are invited to nominate outstanding 1988 books in legislative studies for the Fenno Prize by arranging for publishers to submit three copies of such works to the Fenno Prize Committee. One copy is to be sent to each member of the Committee listed above by March 1. 1989. Authors of prospective nominated books should consult with their publishers to ensure that copies are so sent. The 1989 Richard F. Fenno, Jr. Prize will be announced and conferred at the 1989 Awards Ceremony of the Legislative Studies Section held during and in conjunction with the annual meeting of the American Political Science Association in Atlanta.
The Fenno prize honors the outstanding scholarship of Richard F. Fenno, Jr. of the University of Rochester, the leading contemporary analyst of legislative studies and the 1984-85 President of the American Political Science Association.

\section{Urban Politics and Urban Policy Section Presents Awards}

The APSA organized section on Urban Politics and Urban Policy made the following awards at the 1988 Annual Meeting in Washington, DC:

Norton E. Long, first recipient of the Urban Politics and Policy Career Achievement Award for 1988.

Edward C. Banfield, Special Award for Contributions to Urban Political Theory.

Todd Swanstrom, State University of New York at Albany, Best Book in Urban Politics written during the past five years, for The Crisis of Growth Politics: Cleveland, Kucinich, and the Challenge of Urban Populism (Temple University Press, 1985).

Stephen Elkin, University of Maryland, Best Book in Urban Theory written in the past five years for City and Regime in the American Republic (University of Chicago Press, 1987).

Martin Shefter, Cornell University, Best Book in Urban Policy award for 1988. His book, Political Crisis, Fiscal Crisis: The Collapse and Revival of New York City (Basic Books, 1985) was judged the best urban policy book in the last five years.

\section{Washington Gathering and Book Honor James MacGregor Burns}

During the APSA annual meeting 150 friends gathered to honor James Mac- 